\title{
COMPARATIVE STUDY OF EPIDURAL ANALGESIA IN LABOUR
}

\author{
Niteen Arsule1, Prashant Uikey², Megha Tajane ${ }^{3}$ \\ 1Junior Resident, Department of Obstetrics \& Gynaecology, Dr. V. M. Government Medical College, Solapur. \\ 2 Professor \& HOD, Department of Obstetrics \& Gynaecology, IGMC, Nagpur. \\ ${ }_{3}^{3}$ Associate Professor, Department of Anaesthesia, NKP Salve Medical College, Nagpur.
}

\section{ABSTRACT}

\section{BACKGROUND}

The pain of child birth is one of the most severe types of pain a woman will endure in her lifetime. Epidural analgesia possesses a long record of safety and has few complications and can be considered as standard management for pain relief during labour.

\section{METHODS}

The study comprises of continuous lumbar epidural analgesia with Bupivacaine $(0.125 \%)$ pain relief during labour. A total of 100 cases (Primigravidae) were studied (After written informed consent), out of which 50 received continuous lumbar epidural analgesia and 50 served as control. Perception of pain relief was standardised by using data from Visual analogue scale. Motor power was assessed. Maternal and foetal outcome were noted.

\section{RESULTS}

$30(60 \%)$ of women left their experience with epidural analgesia better than expected; 19 (38\%) patients found it satisfactory and as expected only $1(2 \%)$ patients had inadequate analgesia. A scale measuring from $0-10 \mathrm{~cm}$ was used and pain was assessed before giving epidural analgesia and after giving analgesia. Mean basal VAS before giving epidural analgesia was $8.88 \mathrm{~cm}$. Mean VAS after giving epidural during 1st stage was $1.70 \mathrm{~cm}$ and during 2nd stage was $2.13 \mathrm{~cm}$. Maximal motor blockage assessed by Bromage scale was $96 \%$ and $4 \%$ for grade 0 and 1 respectively.

\section{CONCLUSION}

Epidural analgesia results in significantly satisfactory analgesia with minimal motor blockade, so that patient remains ambulatory.

\section{KEYWORDS}

Parturient, Pain Relief, Epidural Analgesia, Bupivacaine, Maternal and Fetal Outcome, Visual Analogue Scale.

HOW TO CITE THIS ARTICLE: Arsule N, Uikey P, Tajane M. Comparative study of epidural analgesia in labour. J. Evolution Med. Dent. Sci. 2016;5(40):2413-2417, DOI: 10.14260/jemds/2016/562

\section{INTRODUCTION}

Labour and delivery are amongst the most painful of human experiences. Women have been able to cope up with this pain with these extreme conditions, probably in anticipation of the result and that the happy experiences of motherhood would dull the memories of pain. Pain in labour was thought to be essential to the birth process until mid-nineteenth century.

This myth was broken later and it surfaced that child birth should be pleasant and painless experience in human being. Chloroform was used for it first by Simpson. ${ }^{1}$ but he quoted that "It will be necessary to ascertain anaesthesia's precise effect upon the actions of the uterus and abdominal muscles and its influence upon the child." Motor weakness of lower body resulting from epidural analgesia may inhibit normal foetal rotation and descent, particularly when the epidural is administered in latent labour. To address these concerns, modern day epidural analgesia administered during labour consists of low dose of local anaesthetic and adjuvant medications allowing adequate pain relief without significant effects on motor function.

Financial or Other, Competing Interest: None.

Submission 03-03-2016, Peer Review 31-03-2016,

Acceptance 05-04-2016, Published 17-05-2016.

Corresponding Author:

Dr. Niteen Arsule,

Flat No. Snehangan Heights,

Vrundavan Nagar, Behind Jatra Hotel,

Near Kamadhenu Super Market, Nashik-422002.

E-mail: drnitinarsule@gmail.com

DOI: $10.14260 /$ jemds/2016/562
Epidural analgesia may be administered by obstetrician when he or she has been properly trained and in appropriately selected circumstances.

\section{METHODS}

A total of 100 cases (Primigravidae) were studied, out of 50 received continuous lumbar epidural analgesia and 50 served as control; they did not receive epidural analgesia.

\section{Selection of Patients}

Following Criteria were used for Selection of Patients

1. The full term (37-40 wks.) primigravida patient willing for continuous/single shot lumbar epidural analgesia.

2. The presentation vertex and spontaneous vaginal delivery expected.

3. The patient in active labour (Cervical dilatation more than $>3 \mathrm{~cm}$.)

The Contraindication for Epidural Blockade Considered were as follows

1. The patient not willing for epidural analgesia.

2. Abnormal presentation.

3. Previous LSCS.

4. Cephalopelvic disproportion.

5. Antepartum haemorrhage/Hypotension.

6. Coagulation disorders.

7. Spinal deformity.

8. Local sepsis at the site of puncture and systemic sepsis.

9. Known case of sensitivity of local anaesthetic agent.

10. Foetal distress. 
Perception of pain relief is subjective and this variable was standardised by using data from Visual analogue scale.

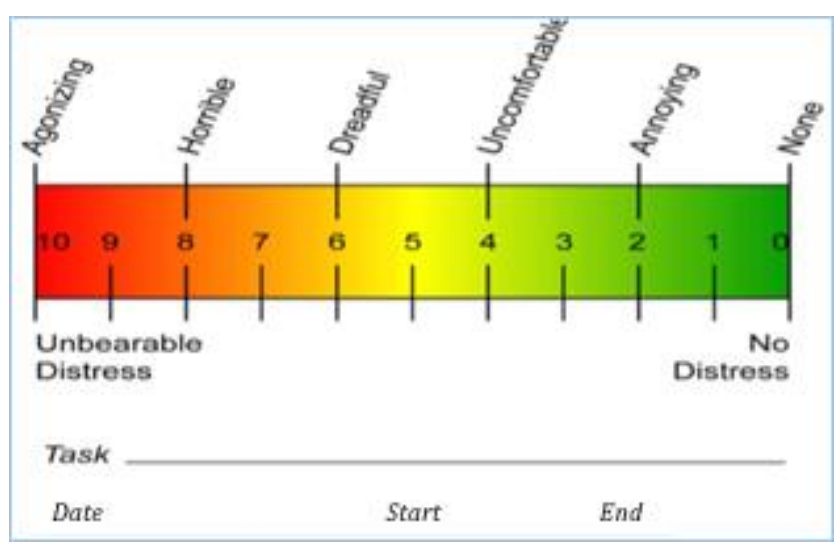

Visual Analogue scale involves the use of $10 \mathrm{~cm}$ scale, which was marked from 0-10 VAS before epidural analgesia; VAS at $5 \mathrm{~min}, 10 \mathrm{~min}, 20 \mathrm{~min}, 30 \mathrm{~min}, 45 \mathrm{~min}, 60 \mathrm{~min}$ and after that half hourly till delivery of baby. Mean VAS is calculated for 1st and 2nd stage of labour. Motor power was assessed using a modified Bromage score at hourly intervals and at each request to get out of bed.

\begin{tabular}{|c|c|}
\hline $\begin{array}{c}\text { Bromage } \\
\text { Score }\end{array}$ & Method \\
\hline 0 & Free movement of legs and feet \\
\hline 1 & $\begin{array}{r}\text { Just able to flex knees; } \\
\text { free movement of feet }\end{array}$ \\
\hline 2 & $\begin{array}{c}\text { Unable to flex knees; } \\
\text { free movement of feet }\end{array}$ \\
\hline 3 & Unable to move legs or feet \\
\hline
\end{tabular}

The degree of motor block was assessed according to a modified Bromage scale before administration of epidural analgesia and 5, 10, 20, 30, 45, 60 min after the first dose of drugs and every 30 min thereafter until delivery. Analgesia was established with $10 \mathrm{~mL}$ of $0.125 \%$ Bupivacaine and maintained with epidural top up doses of the same solution at regular intervals.

If the patients did not receive adequate pain relief within 30 minutes of first dose, $5 \mathrm{~mL}$ of the test solution was repeated at minimum intervals of 5 minutes till adequate analgesia was established. Analgesia was measured using visual analogue scores on a $100 \mathrm{~mm}$ scale. After the initial dose of the test drug, visual analogue scale was measured at the peak of each contraction and the time of onset of first painless contraction noted. The establishment of epidural blockade was tested with skin prick using a needle and the time taken for loss of sensation to pinprick was also noted.

Measurements were performed every $30 \mathrm{~min}$ until delivery. The target for adequate analgesia is said to be attained when visual analogue score is less than $30 \mathrm{~mm}$. The VAPS and the highest dermatomal level of sensory block were assessed using loss of sensation to pinprick was measured before administration of epidural analgesia and 5, 10, 20, 30, 45, $60 \mathrm{~min}$ after the first dose of drugs and every $30 \mathrm{~min}$ thereafter until delivery.

Patients who required instrumental delivery received 10 $\mathrm{mL}$ of the test solution before the procedure in sitting position. Patients who required caesarean section received the test solution till T4 level were achieved.
Motor power was assessed using a modified Bromage score at hourly intervals and at each request to get out of bed. Complications related to epidural like hypotension were noted. The duration of first and second stages of labour were noted. The mode of delivery was noted and if instrumental or caesarean section, the indications for intervention were noted. Neonatal outcome was evaluated by APGAR scores at 1 and 5 mins. Maternal satisfaction with analgesia was assessed by asking the mothers to rate their overall quality of analgesia 24 hrs. after delivery.

\begin{tabular}{|c|c|}
\hline & Satisfaction with Analgesia \\
\hline 1. & Excellent \\
\hline 2. & Satisfactory \\
\hline 3. & Inadequate, No pain relief at all \\
\hline
\end{tabular}

\section{OBSERVATION}

\begin{tabular}{|c|c|c|}
\hline $\begin{array}{c}\text { Duration } \\
\text { (min) }\end{array}$ & $\begin{array}{c}\text { Group A } \\
\text { (n=50) }\end{array}$ & $\begin{array}{c}\text { Group B } \\
\text { (n=50) }\end{array}$ \\
\hline $180-300$ & 18 & 29 \\
\hline $300-420$ & 28 & 20 \\
\hline$>420$ & 4 & 1 \\
\hline MEAN \pm S.D. & $334.66 \pm 71.75$ & $323.48 \pm 71.22$ \\
\hline t test & \multicolumn{2}{|c|}{ P $>0.05$ Insignificant } \\
\hline \multicolumn{2}{|c|}{ Table 1: Distribution Cases According to } \\
Duration of First Stage of Labour \\
\hline
\end{tabular}

$\mathrm{n}=$ number of cases

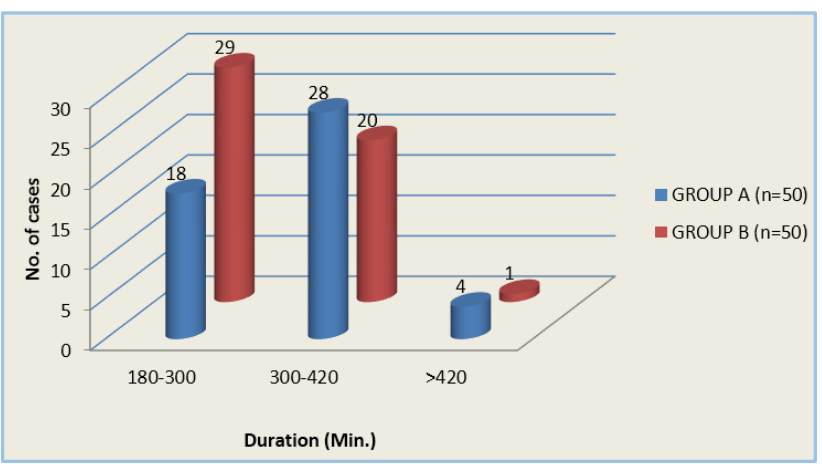

Fig. 1: Distribution Cases According to Duration of First Stage of Labour

Figure on bar shows number of cases.

Mean duration of first stage of labour in Group A was 334.66 min and that for Group B were 323.48 min, and their $P$ ( $t$ test) value was insignificant. So both groups were comparable statistically. So there was no significant difference in duration of labour in study group and control group.

\begin{tabular}{|c|c|c|}
\hline Duration (min) & Group A (n=50) & Group B (n=50) \\
\hline $15-29$ & 7 & 9 \\
\hline $30-44$ & 18 & 22 \\
\hline $45-59$ & 16 & 16 \\
\hline $60-75$ & 5 & 0 \\
\hline MEAN \pm SD. & $41.54 \pm 11.93$ & $37.57 \pm 9.10$ \\
\hline t test & P >0.05 INSIGNIFICANT \\
\hline \multicolumn{2}{|c|}{ Table 2: Distribution of Cases According to } \\
Duration of Second Stage of Labour \\
\hline
\end{tabular}

$\mathrm{n}=$ number of cases 


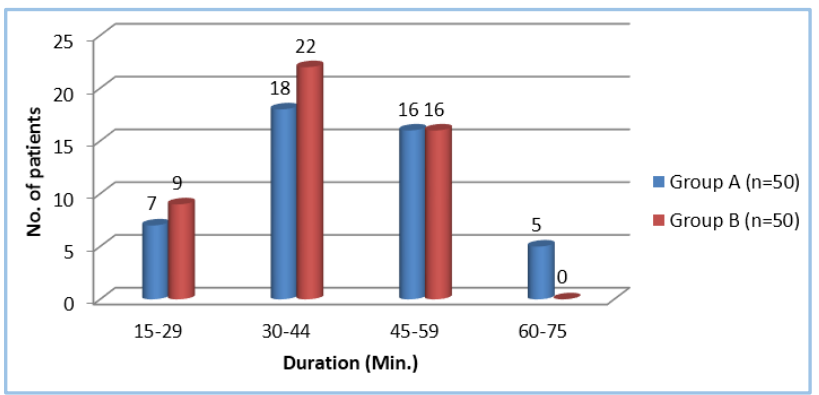

Fig. 2: Distribution of Cases According to Duration of Second Stage of Labour

Figure on bar shows number of cases.

Mean duration of second stage of labour in group A was $41.54 \mathrm{~min}$ and that for group B were $37.57 \mathrm{~min}$, and their $\mathrm{P}(\mathrm{t}$ test) value was insignificant. So both groups were comparable statistically. So there was no significant difference in duration of labour in study group and control group. There was no complication in third stage of labour in both Group A and Group B patients.

\begin{tabular}{|c|c|c|}
\hline Indication & $\begin{array}{c}\text { Group A } \\
(n=50)\end{array}$ & $\begin{array}{c}\text { Group B } \\
(n=50)\end{array}$ \\
\hline Normal Vaginal Delivery & $43(86 \%)$ & $45(90 \%)$ \\
\hline $\begin{array}{l}\text { Instrumental Delivery } \\
\text { (Ventouse) }\end{array}$ & $3(6 \%)$ & $2(4 \%)$ \\
\hline Fetal Distress & $1(2 \%)$ & $1(2 \%)$ \\
\hline Non-Progressive 2nd Stage & $2(4 \%)$ & $1(2 \%)$ \\
\hline Caesarean Section & $4(8 \%)$ & $3(6 \%)$ \\
\hline Fetal Distress & $2(4 \%)$ & $2(4 \%)$ \\
\hline Non-Progressive 2nd Stage & $2(4 \%)$ & $1(2 \%)$ \\
\hline \multicolumn{3}{|c|}{$\begin{array}{l}\text { Table 3: Distribution of Cases } \\
\text { According to Mode of Delivery }\end{array}$} \\
\hline
\end{tabular}

$\mathrm{n}=$ number of cases

\begin{tabular}{|c|c|c|c|c|}
\hline $\begin{array}{c}\text { Sl. } \\
\text { No. }\end{array}$ & $\begin{array}{c}\text { Apgar } \\
\text { Time }\end{array}$ & Score & $\begin{array}{c}\text { Group } \\
\text { A }\end{array}$ & $\begin{array}{c}\text { Group } \\
\text { B }\end{array}$ \\
\hline 1. & At 1 Min & $<7$ & 2 & 1 \\
\hline & & $7-10$ Score & 48 & 49 \\
\hline 2. & At 5 Min & $<7$ & 0 & 0 \\
\hline & \multicolumn{4}{|c|}{$\begin{array}{c}\text { Table 4: Showing Distribution According } \\
\text { to APGAR Score at 1 min and 5 min }\end{array}$} \\
\hline \multicolumn{4}{|c}{} \\
\hline
\end{tabular}

$\mathrm{n}=$ number of cases

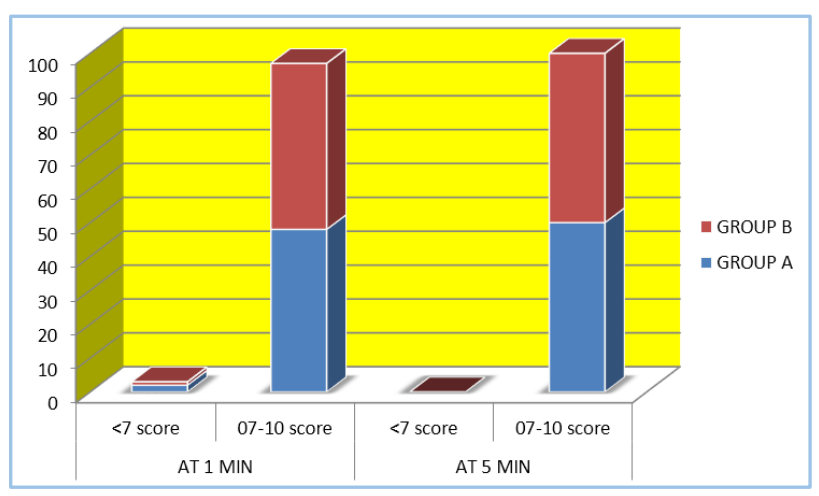

Fig. 4: Distribution of Cases According to APGAR Score at 1 min and 5 min

In Group A 2 (4\%) and in Group B 1 (2\%) neonates had APGAR $<7$ at $1 \mathrm{~min}$. They were resuscitated in the form of suction and stimulation and nasal $\mathrm{O}_{2}$ was given; no neonate needed intubation and any drugs.
Subjective Assessment

\begin{tabular}{|c|c|c|}
\hline $\begin{array}{l}\text { Quality of } \\
\text { Analgesia }\end{array}$ & $\begin{array}{c}\text { No. of } \\
\text { Patients (50) } \\
\end{array}$ & $\begin{array}{c}\text { Percentage } \\
\% \\
\end{array}$ \\
\hline $\begin{array}{c}\text { Excellent } \\
\text { (Better than Expected) }\end{array}$ & 30 & 60 \\
\hline Satisfactory/Good & 19 & 38 \\
\hline Inadequate & 1 & 2 \\
\hline Failure & 0 & 0 \\
\hline Total & 50 & 100 \\
\hline $\begin{array}{r}\text { Table 5: } \\
\text { According }\end{array}$ & $\begin{array}{l}\text { bution of C } \\
\text { lity of Ana }\end{array}$ & \\
\hline
\end{tabular}

\section{Subjective Assessment}

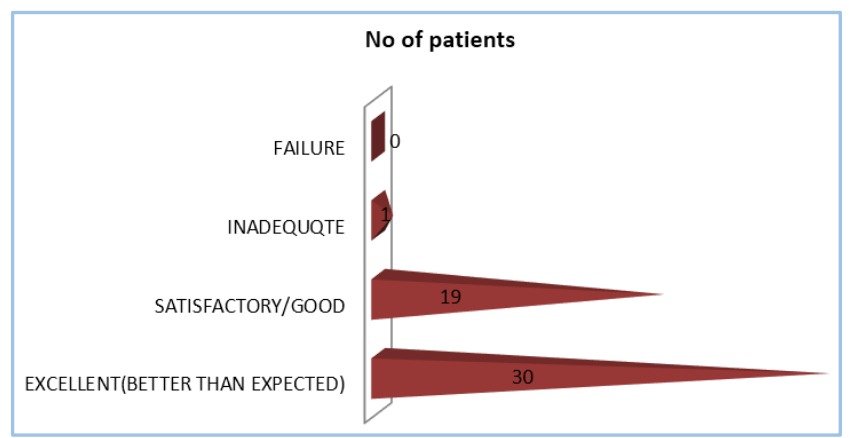

Fig. 5: Distribution of Cases According to Quality of Analgesia

Figure on bar shows number of cases $30(60 \%)$ of women left their experience with epidural analgesia better than expected; 19 (38\%) patients found it satisfactory and as expected only 1 (2\%) patients had inadequate analgesia, i.e. they had significant pain relief but experienced some pain during most of time of labour and delivery.

\begin{tabular}{|c|c|c|}
\hline $\begin{array}{c}\text { Sl. } \\
\text { No. }\end{array}$ & $\begin{array}{c}\text { VAS and Stage } \\
\text { of Labour }\end{array}$ & Mean \\
\hline 1. & Basal VAS (Before Epidural) & $8.88 \mathrm{~cm}$ \\
\hline 2. & $1^{\text {st }}$ stage & $1.70 \mathrm{~cm}$ \\
\hline 3. & $2^{\text {nd }}$ stage & $2.13 \mathrm{~cm}$ \\
\hline \multicolumn{2}{|c|}{ Table 6: Distribution of Cases } \\
According to Visual Analogue Scale \\
\hline
\end{tabular}

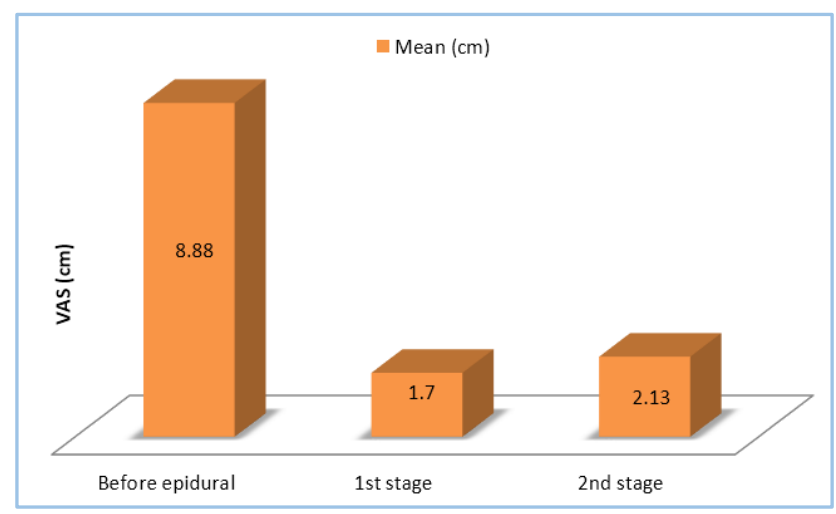

Fig. 6: Distribution of Cases According to Visual Analogue Scale

A scale measuring from $0-100 \mathrm{~mm}(0-10 \mathrm{~cm})$ was used and pain was assessed before giving epidural analgesia and after giving analgesia. 
Mean basal VAS before giving epidural analgesia was $8.88 \mathrm{~cm}$. Mean VAS after giving epidural during $1^{\text {st }}$ stage was $1.70 \mathrm{~cm}$ and during $2^{\text {nd }}$ stage was $2.13 \mathrm{~cm}$. Maternal side effects were seen in $6(12 \%)$. Hypotension was seen in $1(2 \%)$ patients on O.T. Table.

Distribution of patients according to motor weakness by using Bromage scale

\begin{tabular}{|c|c|c|c|}
\hline $\begin{array}{c}\text { Sl. } \\
\text { No. }\end{array}$ & $\begin{array}{c}\text { Maximum Motor } \\
\text { Block }\end{array}$ & $\begin{array}{c}\text { No. of Patients } \\
(\mathbf{n = 5 0 )}\end{array}$ & $\begin{array}{c}\mathbf{( \% )} \\
\mathbf{n = 5 0}\end{array}$ \\
\hline 1. & 0 & 48 & 96 \\
\hline 2. & 1 & 2 & 4 \\
\hline 3. & 2 & 0 & $0 \%$ \\
\hline \multicolumn{3}{|c|}{ Table 7: Distribution of Cases According } \\
to Motor Blockade \\
\hline
\end{tabular}

$\mathrm{n}=$ number of cases

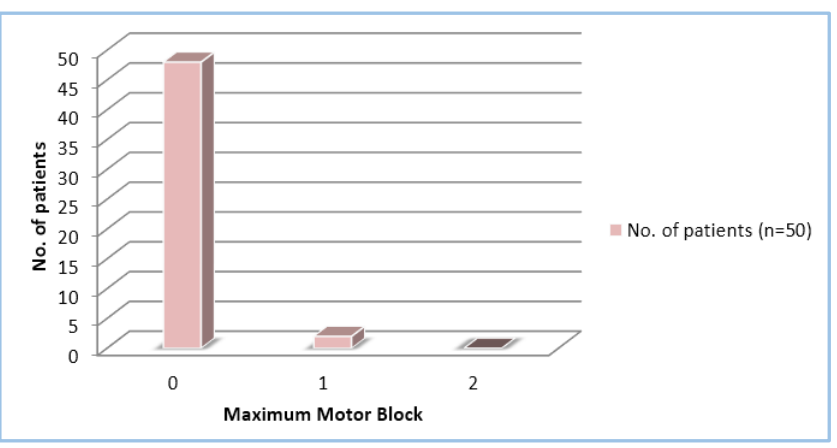

\section{Fig. 7: Distribution of Patients According to Motor Weakness by Using Bromage Scale}

Figure on bar shows number of cases.

All patients remained ambulatory and they could go walking to toilet or sit in a chair at bedside.

\section{DISCUSSION}

Various concentration of different drugs like lignocaine, mepivacaine, ropivacaine, carbocaine, bupivacaine, etc. have been tried for injection into epidural space for pain relief in labour.1,2,3 The first report which appeared in literature using bupivacaine for epidural analgesia was done by E. K. Blom and Widman in 1964. Since then, many studies have been carried. For the present study, $0.125 \%$ bupivacaine was used to study the efficacy of epidural analgesia during labour. 4,5

\section{Duration of $1^{\text {st }}$ and $2^{\text {nd }}$ stage was studied}

As per table number 4 and 5, both Group A and Group B were comparable statistically and there was no significant difference in the duration of labour, as $t$ test $p$ value $>0.05$ is insignificant.

\begin{tabular}{|c|c|c|c|}
\hline $\begin{array}{c}\text { Study } \\
\text { Group }\end{array}$ & $\begin{array}{c}\mathbf{1}^{\text {st }} \\
\text { Stage }\end{array}$ & $\begin{array}{c}\mathbf{2}^{\text {nd }} \\
\text { Stage }\end{array}$ & $\begin{array}{c}\text { Total } \\
\text { Duration }\end{array}$ \\
\hline Stud et al 1980.4 & $480 \mathrm{~min}$ & $57.9 \mathrm{~min}$ & $537.9 \mathrm{~min}$ \\
\hline $\begin{array}{c}\text { Cohen et al } \\
1987.5\end{array}$ & - & $52 \mathrm{~min}$ & - \\
\hline $\begin{array}{c}\text { David Chestnut } \\
1994\end{array}$ & $381 \mathrm{~min}$ & $112 \mathrm{~min}$ & $493 \mathrm{~min}$ \\
\hline $\begin{array}{c}\text { Russell et al } \\
1995\end{array}$ & $299 \mathrm{~min}$ & $104 \mathrm{~min}$ & $403 \mathrm{~min}$ \\
\hline Botill et al 1997 & $269 \mathrm{~min}$ & $46 \mathrm{~min}$ & $315 \mathrm{~min}$ \\
\hline Present study & $\begin{array}{c}334.66 \\
\mathrm{~min}\end{array}$ & $\begin{array}{c}41.54 \\
\mathrm{~min}\end{array}$ & $376.2 \mathrm{~min}$ \\
\hline
\end{tabular}

The present study is comparable with Russell et al 1995.6 for the duration of $1^{\text {st }}$ stage of labour. The present study is comparable with Botill et al $1998 .{ }^{7}$ and Cohen et al 1987. ${ }^{8}$ for the duration of $2^{\text {nd }}$ stage of labour. There was no complication in third stage of labour in both Group A and Group B patients such as retained placenta, PPH, hypotension.

\section{Mode of Delivery}

\begin{tabular}{|c|c|c|c|}
\hline Mode of Delivery & Normal & Instrumental & LSCS \\
\hline $\begin{array}{c}\text { Celleno and Capogna } \\
\text { 1988. }\end{array}$ & $83.3 \%$ & $10 \%$ & $6.6 \%$ \\
\hline Russell et al 1995.6 & $46 \%$ & $40 \%$ & $14 \%$ \\
\hline Dahl et al 1999.10 & $82 \%$ & $9 \%$ & $9 \%$ \\
\hline Hart et al 2003.11 & $51 \%$ & $29 \%$ & $20 \%$ \\
\hline $\begin{array}{c}\text { Desai Pankaj et al } \\
\text { 2006.12 }\end{array}$ & $65.12 \%$ & $25.45 \%$ & $9.43 \%$ \\
\hline Present study & $86 \%$ & $6 \%$ & $8 \%$ \\
\hline
\end{tabular}

In the present study, majority of patients in Group A (86\%) and Group B (90\%) delivered spontaneously without intervention (Table No. 6). The present study is comparable with study Cellano and Capogna 1988. ${ }^{9}$ Dahl et al 1999.11

RCT conducted by Philipsen and Jensen 1989.13 Sharma et al 1997.14 Bofill et al 1998. ${ }^{7}$ Clark and Colleagues 1998.15 showed no significant difference between caesarean delivery rates associated with epidural analgesia as compared to those without epidural analgesia.

In present study also, there is no significant difference between caesarean delivery rates in Group A (Epidural Group) and Group B (Control Group).

Neonatal status - In the RCT by Lriberman et al 1996.16,17 more than 34 studies were identified in which APGAR score of infants was studied between women receiving epidural analgesia and those who did not. Only one study showed a higher proportion, whose mothers received epidural having a 5 min APGAR $<7$.

\begin{tabular}{|c|c|c|c|c|}
\hline & \multicolumn{2}{|c|}{$\begin{array}{c}\text { Group A (Epidural } \\
\text { Group) }\end{array}$} & \multicolumn{2}{c|}{$\begin{array}{c}\text { Group B (Control } \\
\text { Group) }\end{array}$} \\
\hline & $\begin{array}{c}\text { Desai } \\
\text { Pankaj et } \\
\text { al 2006 }\end{array}$ & $\begin{array}{c}\text { Present } \\
\text { Study }\end{array}$ & $\begin{array}{c}\text { Desai } \\
\text { Pankaj et } \\
\text { al 2006 }\end{array}$ & $\begin{array}{c}\text { Present } \\
\text { Study }\end{array}$ \\
\hline $\begin{array}{c}\text { Neonates } \\
5 \text { minute } \\
\text { APGAR } \\
\text { score }<6\end{array}$ & $0.69 \%$ & $0 \%$ & $0.77 \%$ & $0 \%$ \\
\hline
\end{tabular}

In Desai Pankaj et al 2006.13 comparative study in epidural group $0.69 \%$ neonates had APGAR score $<6$ at $5 \mathrm{~min}$ and in control group $0.77 \%$ neonates had APGAR score $<6$ at 5 min, in present study $0 \%$ neonates had APGAR score $<6$ at 5 min in epidural group and control group.

In the present study majority of women $60 \%$ felt their experience as better than expected, i.e. excellent and $38 \%$ women felt it to be as expected, i.e. satisfactory. Only $2 \%$ patients had incomplete analgesia.

Present study is comparable with study of Danilo Celleno and Capogna 1988.9 J. D. Murphy et al 1991.18 Dahl et al 1998.19

\section{Maximum Motor Block: (Table No. 13)}

In the present study, maximum patients had their Bromage score 0 . 
Present study is comparable to study by Chestnut et al 1994. ${ }^{8}$ As the patients had no motor block, they remained ambulatory and were satisfied.

\section{CONCLUSION}

1. Mean duration of first and second stage of labour in epidural group was $334.66 \pm 71.75$ minutes and $41.54 \pm 11.93$ minutes and in control group was $323.48 \pm 71.22$ minute and $37.57 \pm 9.10$ minutes and they were statistically comparable. There was no prolongation of labour in epidural group.

2. Maximum patients delivered vaginally in both groups.

3. The incidence of spontaneous vaginal delivery in epidural group was $86 \%$ and in non-epidural group was $90 \%$.

4. The incidence of instrumental deliveries in epidural group was $6 \%$ and non-epidural group was $4 \%$.

5. Incidence of LSCS in epidural group was $8 \%$ and nonepidural group was $6 \%$.

6. Foetal outcome was good in both epidural and nonepidural group babies. In epidural group, $4 \%$ neonates has APGAR score $<7$ at one minute and in control group $2 \%$ neonates had $<7$ at one minute, but APGAR score at 5 minutes was $>7$ in all neonates in both groups.

7. Pain relief was assessed after $24 \mathrm{hrs}$. by patient's own evaluation. It shows that $60 \%$ of the patients experienced better than expected pain relief, $38 \%$ of the patients were satisfied. Only $2 \%$ patients had inadequate pain relief, but did not feel worse.

8. Basal VAS before epidural was $8.88 \mathrm{~cm}$. The mean VAS during first stage was $1.70 \mathrm{~cm}$ and during second stage was $2.13 \mathrm{~cm}$. All the mothers were happy with quality of pain relief they obtained.

9. Maximal motor blockage assessed by Bromage scale was $96 \%$ and $4 \%$ for grade 0 and 1 respectively. Patients were happy.

\section{REFERENCES}

1. Moore DC, Bridenbaugh LD, Bridenbaugh PO, et al. Caudal and epidural blocks with bupivacaine for childbirth report of 657 parturients. Obstet And Gynaecol 1971;37(5):667-74.

2. Littlewood DG, Scott DB, Wilson J, et al. Comparative anaesthietic properties of various local anaesthetic agents in extradural block for labour. $\mathrm{Br} \mathrm{J}$ for Anaesth 1977;49:75-9.

3. Owen MD, D'Angelo R, Gerancher JC, et al. $0.125 \%$ ropivacaine is similar to $0.125 \%$ bupivacaine for labour analgesia using patient controlled epidural infusion. Anaesth analg 1998;86(3):527-31.

4. Stud JW, Crawford JS, Duignan NM. The effect of lumbar epidural analgesia on the rate of cervical dilatation and the outcome of labour of spontaneous onset. Bri Jrn Of obst And Gyn 1980;87(11):1015-21.

5. Cohen SE, Tan S, Albright GA, et al. Epidural fentanyl/bupivacaine mixtures for obstetric analgesia. Anaesthesiology 1987;67(3):403-7.
6. Russell R, Quinlan J, Reynolds F. Motor block during epidural infusions for nulliparous women in labour. International Journal of Obstetric Anaesthesia 1995;4(2):82-8.

7. Bofill JA, Vincent RD, Ross EL, et al. Nulliparous active labor, epidural analgesia, and caesarean delivery for dystocia. Am J Obstet Gynaecol 1997;177(6):1465-70.

8. Chestnut DH, McGrath JM, Vincent RD, et al. Dose early administration of epidural analgesia affect obstetric outcome in nulliparous women who are in spontaneous labor. Anaesthesiology 1994;80(6):1201-8.

9. Danilo Celleno, Giorgio Capogne. Epidural fentanyl plus bupivacaine $0.125 \%$ for labour analgesic effects. Can J Anaesth 1988;35(4):375-8.

10. Dahl, Hagen I, Koss KS, et al. Bupivacaine $2.5 \mathrm{mg} / \mathrm{ml}$ versus bupivacaine $0.625 \mathrm{mg} / \mathrm{ml}$ and sufentanil $1 \mathrm{pg} / \mathrm{ml}$ with or without epinephrine $1 \mathrm{pg} / \mathrm{ml}$ for epidural analgesia in labour. International Journal of Obstetric Anaesthesia 1999;8:155-60.

11. Hart EM, Ahmed N, Buggy DJ. Impact study of the introduction of low-dose epidural (bupivacaine $0.1 \%$ fentanyl $2 \mu \mathrm{g} / \mathrm{ml}$ ) compared with bupivacaine $0.25 \%$ for labour analgesia. International Journal of Obstetric Anaesthesia 2003;12(1):4-8.

12. Desai $P$, Patel $P$, Gupta A, et al. Epidural analgesia in labor. J Obstet Gynaecol India 2006;56(5):417-22.

13. Philipsen T, Jensen NH. Epidural block or parenteral pethidine as analgesic in labour: a randomized study concerning progress in labour and instrumental deliveries. Eur J Obstet Gynaecol Reprod Biol 1989;30(1):27-33.

14. Sharma SK, Sidawi JE, Ramin SM, et al. Cesarean delivery: a randomized trial of epidural versus patient-controlled meperidine analgesia during labor. Anesthesiology 1997;87(3):487-94.

15. Clark A, Carr D, Loyd G, et al. The influence of epidural analgesia on cesarean delivery rats: a randomized, prospective clinical trial. Am J Obstet Gynaecol 1998;179(6 Pt 1):1527-33.

16. McDonald JS. Pain of childbirth. In: Loeser JD, Editor, Bonica's management of pain. Lippincotts Williams and Wilkins, Philadelphia 2001;3rd edn:1388-414.

17. Bogod DG, Rosen M, Rees GAD. Extradural infusion of $0.125 \%$ bupivacaine at $10 \mathrm{ml}$ per hour to women during labour. BJA 1987;59(3):325-30.

18. Murphy JD, Henderson K, Bowden MI, et al. Bupivacaine versus bupivacaine plus fentanyl for epidural analgesia: effect on maternal satisfaction. British Journal of Anaesthsia 1991;302(6776):564-7.

19. Dahl JB, Jeppesen IS, Jorgensen H, et al. Intra operative and postoperative analgesic efficiency and adverse effects of intrathecal opiods in patients undergoing caesareans section with spinal anaesthesia: a qualitative and quantitative systemic review of randomized controlled trials. Anaesthesiology 1999;91(6):1919-27. 